\title{
"Rock and Roll Will Keep Us Together": \\ Music and the Representations of Yugoslav Collectivity in the Day of Youth
}

\author{
Ana Petrov \\ Faculty of Media and Communications, Singidunum University, Belgrade \\ Beogradska 31/13, 11000 Belgrade, Serbia \\ E-mail: anapetrov82@gmail.com
}

(Received: June 2015; accepted: September 2015)

\begin{abstract}
In this article I will point out to the role of music in the Day of Youth, the most important state holiday in the socialist Yugoslavia. I will show that in the afterwar period, the music for the jamboree was selected in order to highlight certain important events from the People's Liberation Struggle, so that it consisted in the combination of traditional, partisan and folk songs, and it was regularly related to Tito himself. After Tito's death in 1980, the Day of Youth was in crisis, together with the country, but despite that, the celebrations were organized almost until the very end of Yugoslavia. The celebrations after Tito were marked by a tendency to overcome the crisis of the ideology of "brotherhood and unity," so that it was concluded that the Day of Youth should be modernized. I argue that the music played a crucial role in the process, leading to the promulgation of rock and roll as "our future," i.e. the future of the young. The collectivities that were represented in the jamboree also changed in accordance with the music, so that those in the 1980s included casual rock and roll dancing instead of traditional round dances.
\end{abstract}

Keywords: Day of Youth, Yugoslav popular music, Josip Broz Tito, collectivity

\section{Introduction}

The Relay of Youth was a symbolic relay race held annually in the socialist Yugoslavia. The relay carried a baton with a birthday pledge to Josip Broz Tito from all young people of Yugoslavia. The race usually started in Tito's birth town Kumrovec and went through all major towns and cities of the country. It ended in Belgrade at JNA Stadium on May 25, Tito's official birthday, which was proclaimed to be the Day of Youth, a national holiday. May 25 was actually the day Tito sur- 
vived a battle during World War II and not his real birthday, but was announced by Tito as his official date of birth and it was upgraded to the level of a holiday for the whole country. The relay first took place in 1945 and was formalized as a national holiday in 1957 as the Day of Youth. It went on after Tito's death in 1980. The last celebration was organized in 1988, but without the relay procession and in a clearly drastically changed atmosphere that implicated the approaching end of Yugoslavia.

"Rock and Roll Will Keep us Together" is a quotation from the 1984 Day of Youth. It was said by the announcers during TV broadcast and it was one of the symptomatic moments in the history of these public celebrations, since the music was publicly proclaimed to be the possible saving from the coming end of the ideal of "brotherhood and unity" and possibly the end of the country itself. The second part of the title refers to the idea of making the collective body of all Yugoslavs, which was a serious project in the country. The actual bodies were possibly to be shaped due to the investment into the system of free physical education and exercise. The recommended ideal of body was promulgated publicly, one of the ways being public holidays, especially the Day of Youth that represented the central celebration of the year. ${ }^{1}$ Music helped shaping the symbolic representations of this collective body, since the choice of music changed the ways the actual participants of the event were organized in the field.

I will here deal with the following issues: firstly, some information regarding the Day of Youth itself will be explicated, such as its position in the calendar, its importance for the symbolic values of the socialist Yugoslavia and the transformations that the holiday celebration underwent in time; secondly, I will deal with the ways music was incorporated in the celebration; finally, the focus will be on the changes in the music that testify how essential the position and, above all, the choice of music was. As opposed to the readings of the Yugoslav cultural practices as being behind the "Iron Curtain" and strictly regulated by the state apparatus, my theoretical background is in the recent views on the issue of socialism that suggest going beyond the Western/Eastern dichotomies and that point to the multilayered qualities of the Yugoslav society. ${ }^{2}$ From this perspective, the Yugoslav culture is critically approached as a twofold phenomenon. It certainly was an ideological product, however, it does not mean that it was solely the consequence of the totalitarian repression as the supporters of the "repression thesis" claim. Fur-

1. On the role of sport in the formation of the concept of collective body see, for instance, Ozren Biti, "Nadzor nad tijelom: fukoovski pristup sportu" [Surveillance of the body: The Foucauldian approach to sport] Metodički ogledi 19/1 (2012), 37-58; see also Gillian Bendelow and Simon J. Williams, The Lived Body: Sociological Themes, Embodied Issues (London and New York: Routledge, 1998).

2. See for example Socijalizam na klupi: Jugoslavensko društvo očima nove postjugoslavenske humanistike [Socialism on the bench: Yugoslav society from the perspective of post-Yugoslav humanities], eds Lada Duraković and Andrea Matošević (Pula-Zagreb: Srednja Europa, Sveučilište Jurja Dobrile u Puli, Sa(n)jam knjige u Istri, 2013). 
thermore, it can be construed as a result of "lived bodies" that created Yugoslav everyday life. ${ }^{3}$ I want to point out to the fact that by analyzing the role of music in the public celebrations and representations of Yugoslav collectivity, ${ }^{4}$ the crucial political issues of the time can be reconstructed. Also, the Yugoslav politics of music illustrates the means the officials used in order to deal with the problems, trying to find certain solutions at least on the symbolic and cultural level, music being one of them.

\section{The Day of Youth: the functions}

After World War II, in which Yugoslavia was reconstructed by Josip Broz Tito, the cultural politics of the country entailed multifarious strategies for building a single nation under the name "Yugoslavs" that was supposed to be united under the motto "Bratstvo i jedinstvo" (Brotherhood and unity). ${ }^{5}$ This concept was important in a project used for the formation of Yugoslav identity and the creation of a new "Yugoslav body." "Trying to construct an image of a progressive modern leader, in 1956 Josip Broz Tito proclaimed his birthday to be "the day of our youth, sport, young people and their further physical and spiritual progress,"7 thus connecting himself with the most important part of the nation - the young. Becoming a national holiday, Tito's birthday was prepared during the whole year. The documentation in the Archives of Yugoslavia, especially the documents from the fond of Yugoslav Association for Physical Training provide a clear insight into the ways and intensity of the preparation for this holiday. The documentation shows how long, complex, and painstaking this process of preparation could be: there were usually at least two drafts of the possible scenario for the final celebration; each of them was analyzed and only the best suggested solutions were accepted; also, after one celebration was over, it was immediately discussed about,

3. The concept of lived body critically examines the notion of human embodiment in social thought. By using the notion of embodiment to transcend the dualist legacies of the past, this approach argues that the body is not simply a "textual effect" or "discursive construct." Rather, embodiment is the active basis of being in the world, and the foundation of self, meaning, culture, and society. Thus, the question of choosing between experience and representation has been changed to exploring their dialectical relationship to one another, and the emergent properties contained therein. Bendelow and Williams, The Lived Body, 1-9.

4. Rather than using the terms "community" or "collective," I chose the term "collectivity," which implies the flexible and non-permanent nature of a specific group of people. See also John Urry, Sociology Beyond Societies: Mobilities for the Twenty-first Century (London: Routledge, 2000).

5. The Socialist Federal Republic of Yugoslavia was a socialist state and a federation made in the aftermath of World War II and existed until 1991. It was made up of six socialist republics: Bosnia and Herzegovina, Croatia, Macedonia, Montenegro, Serbia, and Slovenia, and, in addition, included two autonomous provinces: Vojvodina and Kosovo.

6. Srđan Atanasovski and Ana Petrov, "Carnal Encounters and Producing Socialist Yugoslavia: Voluntary Youth Labour Actions on the Newsreel Screen," Studies in Eastern European Cinema, 6/1 (2015), 21-32.

7. Titova štafeta. Štafeta mladosti [Tito's relay. The Relay of Youth], ed. Ljubica Staimirović (Beograd: Muzej 25. maj, 1985), 22. 
and sharp critical remarks were common part of the organizational process for the next year. ${ }^{8}$

The Day of Youth had one essential function: to construct (discursively) and produce (practically, bodily and emotionally) the identity of a Yugoslav. And this was done on three levels: making the unity of Yugoslav youth, producing normative (collective) body (due to the concept of physical culture) ${ }^{9}$ and regulating everyday life, since the organization of the year was made so that the highest point of it was the celebration that actually represented everything an average Yugoslav was supposed to do on regular basis, like doing sports or listening to certain music. The role of physical culture was to organize Yugoslav society physically and aesthetically and then to incorporate concepts and movements from gymnastics into broader concepts of united Yugoslav youth presented in public celebrations, the most typical being firstly the Relay of Youth, later just the Day of Youth in which the relay procession had central part. ${ }^{10}$ The ideals upon which the new afterwar society rested, such as the ideology of "brotherhood and unity," the cult of labour and the legacy of the Partisan struggle, ${ }^{11}$ were practiced as daily rituals and they were connected to the idea of creating a "new socialist man," a young person who creates, propagates and embodies the ideas of the new socialist state in their daily life. ${ }^{12}$

Another important segment of Yugoslav politics that was incorporated in public celebrations was the pioneer culture. Founded in 1942 in Bihać, Bosnia and

8. The preparation included the analyses of the potential parts of the celebration, choreographies, participants and music. It was important for the celebration to be interesting enough but also efficiently representative for the state ideology. Završna priredba za dan mladosti - scenario - idejne skice za Dan mladosti 1965 [Closing ceremony for the Day of Youth - Script - Ideas for the Day of Youth], Archives of Yugoslavia, Belgrade, Fond Saveza za fizičku kulturu Jugoslavije [Fond of the Yugoslav Association for Physical Training], F-139, 315/1964.

9. The conceptual and discursive level of promulgation of the concept of physical culture had as its consequence very specific investments and plans that were made in order to make the idea functional and real in the lives of the people. Thus, the idea that physical culture was extremely important was being made possible since the time and place were planned for the actual engagement in the multifarious physical activities. People in Yugoslavia had the chance to do sport almost anywhere, during working hours (pauses for physical exercise were planned), as well as during trips and organized vacations. Furthermore, there were controls in the field aimed at verifying whether the decisions of the Central Committee of the Communist Party were carried out.

10. Such a celebration was not completely new, but rather it drew on the "Sokol" that were organized in honor of the prince Petar Karađorđević. Organized before World War II, they are considered to be the predecessors of the later Relay of Youth. Dimitar Grigorov, "Računajte na nas: Odlomak o Titovoj štafeti ili Stafeti mladosti” [Count on us: Tito's baton or youth's baton], Godišnjak za društvenu istoriju [Annual for social history] 15/1-3, (2008), 105-136. See also Nikola Žutić, "Liberalizam hrvatskih, srpskih i jugoslavenskih Sokola (1862-1991)" [Liberalism of Croatian, Serbian and Yugoslav Sokols (1862-1991)], Dijalog povjesničara/istoričara [Dialog of the historians] 5 (2002), 305-322.

11. The National Liberation Army was one of Europe's anti-Axis resistance movements during World War II. The Yugoslav Resistance was led by the Communist Party of Yugoslavia whose commander was Marshal Josip Broz Tito. After the war, the legacy of the partisan struggle was one of the key elements in the public celebrations in Yugoslavia.

12. Starting from the 1950 s, when solid foundations had been made, there was a dominant tendency of making sport activities present in everyday lives of the Yugoslavs, which was officially labelled as 'omasovljenje' [making the sport to be available to the masses]. 
Herzegovina, at the $1^{\text {st }}$ Congress of the United Alliance of Anti-Fascist Youth of Yugoslavia, the Pioneer Alliance of Yugoslavia had its origin in World War II and the National Liberation Movement. For the first eight years it was tied to the youth organization, but then it was put under the jurisdiction of the newly established Council of the Pioneer Alliance and the republican and federal organizations for the care and upbringing of children. Throughout the socialist period, all first graders at the age of six or seven were admitted to the organization and stayed members until the seventh grade, when at the age of thirteen or fourteen they entered the Alliance of Socialist Youth. As pioneers, children were active through the sections in elementary schools and took part in different activities. A few times a year, on state holidays, anniversaries and special events, children would wear their pioneer uniforms of regular dark blue trousers or skirts and white shirts or blouses. The symbols and the idea of such an organization found direct inspiration in the Soviet pioneers, a fact which made some want to disband the pioneer organization after the Yugoslav-Soviet split in 1948. However, the Pioneer Alliance survived and was active until the late 1980s. ${ }^{13}$

The Day of Youth celebration had three phases in its development: the 1940s and the 1950s (the afterwar period); the 1960s and the 1970s (characterized by the stability in the organization); and the 1980s (the decade in which the economic crisis in the country and in many aspects of Yugoslav culture was apparent and inevitable). However, the history of the Day of Youth can also be divided into two periods: before and after Tito's death, since this historical moment marked the whole Yugoslav politics, culture, significantly affecting the celebration of this public holiday and especially the usage of music in it. ${ }^{14}$

\section{The symbolic roles of the music in the Day of Youth}

Some of the crucial means that helped highlighting the symbolic meanings of the Day of Youth can be found in the mentioned Tito's cult, in the idea of representation of the youth, as well as in the representation of physical potentials and results of the Yugoslavs. Above all, the gist of the celebration is to be found in the symbolic and visual demonstrations of the cult of "brotherhood and unity" in the stadium where the celebration took place. The target groups for the incorporation of

13. On the pioneers and socialist ideology see Igor Duda, Danas kada postajem pionir: Djetinjstvo $i$ ideologija jugoslavenskoga socijalizma [The day when I become a pioneer: Childhood and the ideology of Yugoslav socialism] (Zagreb: Srednja Europa, 2015).

14. According to the news from that period and some personal testimonies, the death of Josip Broz Tito was a very traumatic moment for the majority of the inhabitants of former Yugoslavia, including the people in the sport. Maja Brkljačić, “Tito's Bodies in Word and Image," Narodna umjetnost 40/1 (2003), 99-127. 
all aspects of Yugoslav ideology were the pioneers, the young and the workers, ${ }^{15}$ all of them being also extremely important for the visual and musical solutions of this public celebration.

Bearing all of this in mind, the choice of music and the suitable choreography was certainly the most important part of the celebration for the Day of Youth. Firstly, the music had a constructive function. Since a "slet" (jamboree) contained musical numbers, the organization of it was made in accordance with the kind of music that was chosen and the place of musical numbers in the whole ceremony. Furthermore, the music had huge symbolic potential, since in fact it represented current Yugoslav values and the state of affairs in the country, mostly through choreographic solutions. It could represent stability (by the usage of the songs that were considered to sound "cheerful," or the songs in major without significant usage of dissonances) or crisis (typically represented by dissonances and disorder in choreographies, such as broken round dance) and, which was most often the case, the unity of all nationalities in Yugoslavia (usually represented in a round dance of all the groups in the field).

In the post-World War II period, the music for the jamboree consisted partly of the combination of traditional, partisan and folk songs, often in different arrangements which represented the musical illustrations of different important events related to the history of Yugoslavia and Tito's role in it, such as the partisan struggle. Music demonstrated the great historical past and the role of Yugoslavia in World War II. This contained the following: the representation of unity, the representation of military power and the stability of the country, the promotion of Tito as the leader, his role in the war. The dance choreographies usually served to highlight these moments, so that it was chosen to help sportspersons in the field to do their own presentations of their bodies that had been made during the whole year. Also, the music often included folk representations of the collective body, united in joined choreographies. Typically, a few groups in the field (members of the folk societies) were organized to play different folk dances from divergent parts of Yugoslavia. Joined together in the field, although playing different folk dances, the participants were supposed to represent the unity on the symbolic level. Partisan and mass songs composed earlier or for the occasion of a specific celebration (usually by composers who themselves were involved in the partisan movement during the war) were also regularly performed. ${ }^{16}$

15. On certain aspects of the cult of labour see: Dragan Popović, "Youth Labor Action (Omladinska radna akcija, ORA) as Ideological Holiday-Making," in Yugoslavia's Sunny Side: A History of Tourism in Socialism (1950s-1980s), eds Hannes Grandits and Karin Taylor (Budapest: Central European University Press, 2010), 279-303.

16. One of the most famous authors active during and after the war was Nikola Hercigonja. One of the important characteristics of the partisan songs, such as, for example, Hercigonja's "Naša pjesma" [Our song], was that they described the interaction and congeniality between the landscape and the Yugoslav partisan struggle. These images were available to the population of the new socialist Yugoslavia through the intense activity of choir societies whose repertoire generally included partisan songs. Srđan Atanasovski, "Nikola Hercigonja 
However, after Tito's death in 1980, the Day of Youth was in crisis together with the country it celebrated, although the celebrations were being organized until the end of the decade. ${ }^{17}$ The process of constructing Yugoslav culture started after World War II, the period of the greatest efforts being in the 1950s and 1960s. According to many interpretations, Josip Broz Tito was perceived as standing for the constitutive concept ("brotherhood and unity") of the socialist Yugoslavia, even personifying the country itself. It seems that Tito stood with his body for the other body of the country (body politic of Yugoslavia). As Brkljačić points out, this was not the body made incorporeal, quite the contrary: it was Tito's real, natural body that was not only the embodiment of central power, but that, paradoxically, was the name and the face of what was supposed to be the continuous Yugoslav social body. ${ }^{18}$ Furthermore, his politics were trying so hard to make another body for a few decades: the body of the Yugoslavs. According to the archival material from the 1980s, the collective representations of the Yugoslav body underwent tremendous change - public celebrations were in crisis, since there was an attempt to keep Tito alive, together with the quintessential Yugoslav idea of "brotherhood and unity," epitomized in the idea of representations of the Yugoslav body. However, all these ideas had started their disintegration. The problem was rather simple: with Tito having been present in the celebration, the whole ceremony was devoted to him; however, after his death, there was a tendency to somehow fill in the gap of his absence.

The documents from the 1980s show that there were often discussions on whether the cult of Tito should be kept alive and there were certainly tendencies to do so, one of the most typical being the presence of his image instead of Tito himself in the stadium. In addition, the preparations for this day show that there were problems regarding the representations of the allegedly still present idea of "brotherhood and unity." It was difficult to find the solution for the whole ceremony, the music included, that would epitomize the ideals of that historical moment. The ideas previously used were proved to be out of date, such as partisan

i proizvođenje jugoslovenske nacionalne teritorije" [Nikola Hercigonja and the production of the Yugoslav national territory], in Nikola Hercigonja (1911-2000): Čovek, delo, vreme [Nikola Hercigonja (1911-2000): The Man, the Opus, Time] eds Mirjana Veselinović-Hofman and Melita Milin (Beograd: Muzikološko društvo Srbije, 2011), 133-151. Thus, the songs that were used in the Day of Youth celebrations had often been already known to the audience. One of the most famous songs used in the Day of Youth was "Uz Maršala Tita" [With Marshal Tito], a Yugoslav partisan anthem written by Vladimir Nazor and composed by Oskar Danon.

17. The cult of Tito was being transformed, the art and music being a relevant segment of it. All of the changes in the country were visible in the solutions of the Day of Youth. See Dragan Čalović, "Učešće jugoslovenske posleratne umetnosti u učvršćivanju imidža Josipa Broza Tita" [The participation of Yugoslav postwar art in reinforcing the image of Josip Broz Tito], Kultura polisa 8/15 (2011), 177-194. See also Rade Pantić, "Političko nesvesno identiteta Josipa Broza Tita u likovnim umetnostima, muzici, medijima i javnim priredbama" [Political unconscious of Josip Broz Tito's identity in visual art, music, media, and public celebrations], in Istorija umetnosti u Srbiji - XX vek: Realizmi i modernizmi oko hladnog rata [History of art in Serbia - 20th century: Realisms and modernisms during the Cold War], ed. Miško Šuvaković (Beograd: Orion art, 2012), 241-252; Brkljačić, "Tito's Bodies".

18. Čalović, "Učešće jugoslovenske," 99. 
struggle and the legacy of World War II. Together with the symbolic presence of the former leader, whose picture was always present in the stadium, the symbolic values of the past were transformed. However, all the time, the idea that marked all these celebrations from the beginning until the end is the idea of "brotherhood and unity." Being obviously in danger after Tito's death, this idea was promoted with the help of something that seemed to be one of the most influential Yugoslav products - the Yugoslav pop music. One of the ideas promoted in the late 1980s was that the music of the youth would "keep us together," thus choosing popular music and rock and roll to be played during the public celebration of the Day of Youth (instead of the music composed in honor of Tito or the music from the People's Liberation Struggle). ${ }^{19}$

Trying to overcome the change in the country and to pacify the crisis of the ideology of "brotherhood and unity," the organizers embarked on the project of modernizing the celebrations by changing the arrangements of the old folk or traditional songs with the use of synthesizers, rhythm machines, and rock drums. From the middle-1980s rock and roll was even promulgated as "our future", since it was considered to be the music of the youth, thus being the chance to "keep us together" and reconnect the disappearing collective body that was supposed to be presented in these celebrations and that was obviously already disappearing during the 1980s. Up to the 1980s, the music could include folk, partisan, or it was specifically composed for that occasion. Even when the genre musically resembled a certain kind of pop music, it was politically engaged music, such as the songs on the Communist Party or Tito himself. One typical example is a song entitled "Tito je naše sunce" (Tito is our sun) performed in the 1979 Day of Youth, the last celebration with Tito being present. Composed by one of the most famous Yugoslav pop music composers Kornelije Kovač, the song sounds as if it were a regular pop ballad, while the lyrics, written by Pero Žubac, reveal that it is a song about Tito and the values that were promoted in the socialist Yugoslavia. The representative verses are in the refrain:

Tito is our sun! Tito is our heart! Our happiness is endless;

Only one love keeps on growing! People, party, youth, army! ${ }^{20}$

The politics of the music engagement was changed. Since obviously the heroic past was not truly relevant for Yugoslavia in the 1980s, the solution was to focus on what was a part of the life of every Yugoslav. And pop music certainly was. The Yugoslav music was most certainly a brand in that country and it has always been tightly interconnected with current political state of affairs. Namely in the

19. Grigorov, "Računajte na nas," 115.

20. Available online under: https://www.youtube.com/watch?v=hsrNP3QD3YI (last accessed on 10 September 2015). 
1950s, the Yugoslav popular music culture emerged through the development of local festivals, radio programs and a recording industry. The development of the Yugoslav popular music culture at this time was both rooted in international cultural trends and shaped by the domestic policies that were pursued by the ruling League of Communists of Yugoslavia. After the split with the Soviet Union in 1948, Yugoslavia started producing music that was constantly between the East and the West and the debate on the expectations from that music was present all the time. ${ }^{21}$ In that aspect, the turning to the music as the solution for the Day of Youth was not surprising. By the 1980s, Yugoslav pop and rock were on their highest points, widely popular both in the country and even abroad. Thus, it really seems in accordance with current situation that, on the symbolic level, it was the Yugoslav popular music that had the power to help saving the symbolic values of the country, thus keeping the most important day of the year in Yugoslavia still functional in the state politics.

As it was mentioned above, pop music was proclaimed publicly as a symbol of "our" present unity and as "our" future. But it was not enough. The following strategies were needed to make this project successful. There were three ways the organizers used the music as a symbol of disintegrated unity. Firstly, there was the usage of popular genres. Instead of the strict military atmosphere, remembrance of the heroic partisan past and playing the traditional folk dances, rock and roll was casually played in the middle of the field by cheerful young people who were casually and colorfully dressed. The symptomatic scene was arranged in 1987: the dancers started playing one traditional round dance in popular arrangement, all together. After some time, they began separating one by one, which was followed by the commentator of the TV broadcast by the following words:

What is happening, the round dance is not united, Serbia dances separately, then Croatia, and how Bosnia and Herzegovina. Each group plays its own round dance, why are they eight different round dances, why are they playing to their own national melodies and not together? It seems that we are not united as we should. This is a warning; we cannot dance within eight different systems...22

This comment was musically followed with usage of dissonant chords during the symbolic breaking up of Yugoslavia. And then, after a while, they were united again, and it was due to, as the commentators stated, dancing of "rock round dance" together. That was actually the same composition just in a rock-like style arrangement. The commentator's words were the following:

21. See Dean Vuletic, “The Making of a Yugoslav Popular Music Industry," Popular Music History 6/3 (2011), 269-285.

22. Available online under: https://www.youtube.com/watch?v=OoiZcwae-d0 (last accessed on 10 September 2015). 
Rock is what unites us in everyday life. And it should unite us here. The young, of course, believe in a better future, and that is only the future in which we are all together. ${ }^{23}$

The second way of promoting pop and rock music was the actual appearance of popular musicians, the performance of their songs, or the songs on Yugoslavia in their arrangements. Some of the most popular performers, even figures recognized as the icons of the Yugoslav popular music scene (such as Zdravko Čolić, Željko Bebek, Josipa Lisac, Zorica Kondža, popular Yugoslav groups such as Novi fosili), were involved in the celebration of the Day of Youth, all of them singing about Yugoslavia, although all of them being representatives of rather different kinds of popular music in Yugoslavia. Moreover, the choreographies were made to actual songs (not those related to Yugoslavia or Tito) played by popular Yugoslav pop musicians. Furthermore, some of the songs about Yugoslavia were adapted to the styles of their performers, so that Josipa Lisac performed a patriotic song in her own recognizable jazz like style, ${ }^{24}$ Novi fosili played light pop, ${ }^{25}$ Zorica Kondža and Oliver Dragojević in a Dalmatian canzone-like song, and the like. ${ }^{26}$ One of the most popular songs (still very well known) were "Druže Tito, mi ti se kunemo" (Comrade Tito, we swear to you) composed by a famous Yugoslav pop music composer Đorđe Novković and sung by a famous singer Zdravko Čolić, and "Zemljo moja" (My country) sung by the group Ambasadori and Ismeta Krvavac, also composed in a light pop manner by a famous Sarajevo musician, Kemal Monteno. ${ }^{27}$

Here is one specific and very symptomatic example to point out to the ways the music was used as a means for symbolic fixing of the broken "brotherhood and unity." As early as 1984, a singer now regarded as a legend of the Sarajevo rock music scene, Željko Bebek, a singer of the famous group Bijelo dugme, sang a song entitled "Drugarska" (A song of the friends), whose music is similar to the songs of Bijelo dugme, but the text is actually a prayer, not of the Yugoslavs in general, not of the young, but the children, who ask their parents to let them live long enough to grow up:

23. Ibid.

24. The song "Lice mladosti" [The face of the youth], performed during the 1983 Day of Youth. The recording is available online under: https://www.youtube.com/watch?v=N06nKr5m1RQ (last accessed on 2 October 2015).

25. The song "Mi domovinu imamo" [We have a homeland] played in the 1982 Day of Youth. See https:// www.youtube.com/watch?v=b-lnr5Ppw7U (last accessed on 1 October 2015).

26. See also Vesna Mikić, "Muzika kao sredstvo konstrukcije i rekonstrukcije revolucionarnog mita: Dan mladosti u SFRJ" [Music as a means of construction and reconstruction of the revolutionary myth - Youth's Day in the Socialist Federal Republic of Yugoslavia], Zbornik Matice srpske za scensku umetnost i muziku 40 [Matica Srpska journal of stage arts and music] (2009), 129-136.

27. Both of the mentioned songs, like many others, were not composed for the actual celebration, but were performed in the festivals, the first one in the Festival of Revolutionary and Patriotic songs in Zagreb in 1977, while the second one in the festival Vaš šlager sezone [Your hit of the season] in Sarajevo, 1975. 
The war should not happen to us

Just that we could prove that we are patriots

The war should not happen to us so that we can be heroes

Isn't that the case, my friends!

This song is obviously a call for peace. Listening to a song that belonged to a kind of music that was extremely popular at that time (it sounds as any other song performed by this singer), the Yugoslavs were asked to think about their children's future. It is evident how far from the previous phase this celebration was, even though just a couple of years later.

\section{Concluding remarks}

It is clear that the change in the choice of music was in accordance with current cultural politics in Yugoslavia and it was certainly the consequence of the crisis in Yugoslavia in the last phase of its existence. It seems that the music was one of the last possible solutions, at least on symbolic level and, possibly, on the level of regulation of everyday life, for pointing to the approaching tragic end of the country. The music in the most important holiday in Yugoslavia was obviously changed from celebrating the heroic past, via glorifying the pop music as a possible solution, towards the prayer.

The post-Yugoslav space is also musically intriguing. One of the relevant questions that should be further asked is: If the collectivity was being made physically, emotionally and musically both in everyday life and in public presentations, what has happened to that collectivity? It could not disappear together with Yugoslavia, since we are talking about real people, who may not live as they used to, but they can certainly choose to listen or not listen to Yugoslav music. Hence, my final and further question for my research is: has the Yugoslav collectivity survived the end of Yugoslavia due to one of its firmest products: the music? 